\title{
Example of stress evaluation for a pipe subjected to impeded thermal expansion according to ASME code
}

\author{
Costin Ilincă $^{1}$, Maria Tănase ${ }^{1}$, Marius Gabriel Petrescu ${ }^{1}$ \\ ${ }^{1}$ Mechanical Engineering Department, Petroleum and Gas University of Ploiești, \\ Romania \\ *E-mail: pmarius@upg-ploiesti.ro
}

\begin{abstract}
This material summarizes the results regarding the analysis of the mechanical stress states for a piping system subjected to impeded thermal expansion. It were considered different load cases corresponding to the primary loads (own weight + internal pressure) and the secondary loads (induced by thermal expansion, including the thermal displacements of the equipment connection points). The stresses values determined for each load cases were compared with the allowable limits evaluated according to ASME B31.3 code, resulting that the analyzed piping system is safe.
\end{abstract}

Keywords: piping system, ASME code, stress, finite element analysis, load cases.

\section{Introduction}

The pipeline systems are sets of elements and devices separating a closed tubular space from the environment, mounted on a precisely determined route, which serve to collect, transport and distribute (technological) working environments in different states of aggregation (fluid $\rightarrow$ liquid , gaseous, liquefied, fluidized, powdery, etc.).

The main components of a piping system are the pipes $\rightarrow$ the pipes or tubes that tightly separate/delimit the closed space through which the working environment is conveyed.

The strength calculation regarding the pipe systems has, as a rule, a verification character, it usually succeeding the dimensioning of the pipe elements and the establishment of the pipe route configuration.

Therefore, the strength calculation for a piping system usually takes into account its piping (including bends/curves associated with changes of direction, reductions related to section changes or possible tubular branches).

The article summarizes the results of the analysis of the mechanical stress states identified at the level of a piping system subjected to impeded thermal expansion.

The analysis objectives were:

- evaluation of the states of (thermo) mechanical stresses in the wall of the pipe tubular material, under the action of the applied loads and verification of the corresponding conditions of mechanical resistance;

- evaluation of loads on pipe supports;

- quantification of the reactions level in the equipment connections;

- validation of the maximum pipe displacements;

- checking the removable joints by flanges. 


\section{Analysis code and basic assumptions}

The strength calculation of the tubular material of the pipes and the reactions evaluation in the equipment connections were performed according to the precepts of the North American Code ASME/ANSI B 31.3 [1] - "Process Pressure Piping Code" - Ed. 2006, for pressurized pipe systems used in the industries process (respectively oil refining, petrochemistry, chemistry, etc.).

The analysis of the mechanical stress states developed in the aforementioned pipe system was performed through the specialized calculation program Caesar II [2], Version 5.3.

The system installation temperature was considered $t_{\text {inst }}=+21{ }^{\circ} \mathrm{C}$.

The loads from thermal expansion correspond to the temperature variation of the pipes metallic wall from the installation temperature $\left(t_{\text {inst }}=+21{ }^{\circ} \mathrm{C}\right)$ to the calculation temperature (respectively the maximum allowable working temperature, $t_{\text {calc }}$ ), on the one hand and, respectively, from the minimum temperature of the metallic wall $\left(t_{\min }=-29^{\circ} \mathrm{C}\right)$ up to the installation temperature $\left(t_{\text {inst }}=+21{ }^{\circ} \mathrm{C}\right)$, on the other hand. In these circumstances, the calculations regarding the pipes structural integrity were performed according to the calculation temperature.

The internal pressure loading of the pipes tubular material corresponds to the action of the calculation manometric pressure (or maximum allowable, $P_{c}$ ).

The intensity of the seismic distributed load was evaluated according to P100 code [3]. Thus, the maximum calculation value of the horizontal seismic acceleration at the pipeline level is given by the formula:

where:

$$
a_{s}=\left(\gamma_{C N S} \cdot \beta_{C N S} / q_{C N S}\right) \cdot a_{g}
$$

$\gamma_{C N S}=$ the structure importance factor; in case of the investigated pipes it was considered the covering value $\gamma_{C N S}=1.50$;

$\beta_{C N S}=$ the structure dynamic amplification coefficient; it was adopted the covering value $\beta_{C N S}=2.50$;

$q_{C N S}=$ the structure behaviour factor, depending on its deformation and energy absorbtion capacity; it was adopted the typical value $q_{C N S}=2.50$;

$a_{g}=$ the seismic calculation acceleration of land, established according to the seismic zoning map; for the area of Dobrogea and the Black Sea Coast, $a_{g}=0.16 \cdot g\left(g=9.81 \mathrm{~m} / \mathrm{s}^{2}\right.$ is the gravitational acceleration).

Therefore:

$$
a_{s}=(1.50 \times 2.50 / 2.50) \cdot(0.16 \cdot g)=0.24 \cdot g\left(\mathrm{~m} / \mathrm{s}^{2}\right)
$$

The wind loads were evaluated according to NP-082-04 [4] - see table 1.

Table 1. Wind loads expression [4].

\begin{tabular}{|l|}
\hline $\boldsymbol{w}(z)$ - wind pressure at height $z$ above the ground \\
\hline$w(z)=q_{r e f} \cdot C_{e}(z) \cdot C_{p}$ \\
\hline$C_{p}$ - the aerodynamic pressure coefficient \\
\hline$C_{p}=1$, according to Chapter 12 \\
\hline$q_{r e f}$ - reference wind pressure \\
\hline$q_{r e f}=0.5$, according to figure A2 - Annex A \\
\hline$C_{e}(z)$ - exposure factor at height $z$ above the ground \\
\hline$C_{e}(z)=C_{g}(z) \cdot C_{r}(z)$ \\
\hline$C_{g}(z)-$ burst factor \\
\hline$C_{g}(z)=1+g \cdot[2 \cdot I(z)]$ \\
\hline$g-$ peak factor \\
\hline$g=3.5$, according to Chapter 10.2 \\
\hline
\end{tabular}




\begin{tabular}{|l|}
\hline$I(z)$ - turbulence intensity for open field \\
\hline$I(z)=1 /\left[\ln \left(z / z_{0}\right)\right]$ \\
\hline $\mathbf{z}$ - construction height \\
\hline$z_{0}$ - roughness length \\
\hline It was taken $\mathrm{z}_{0}=0.3$, according to Chapter $7.2-$ Table 1 \\
\hline$C_{r}(z)$ - roughness factor, according to Chapter 8.4 \\
\hline$C_{r}(z)=k_{r}\left(z_{0}\right) \cdot\left[\ln \left(z / z_{0}\right)\right]$ \\
\hline$k_{r}\left(z_{0}\right)=0.22$, according to Chapter 8.2 - Table 2 \\
\hline
\end{tabular}

It resulted the calculation values presented in table 2.

Table 2. Calculation values for wind pressure.

\begin{tabular}{|c|c|}
\hline $\boldsymbol{z}[\mathbf{m}]$ & $\boldsymbol{w}(\boldsymbol{z})[\mathbf{k P a}]$ \\
\hline 5 & 0.67 \\
\hline 10 & 0.89 \\
\hline 15 & 1.03 \\
\hline 20 & 1.14 \\
\hline 30 & 1.29 \\
\hline
\end{tabular}

At the suppports level of the investigated pipes, the sliding friction between the components of the respective supports (slipper-base plate, slipper/profile-limiter, etc.) was taken into account. For the steelsteel contact, the slip friction coefficient was adopted at the standard value 0.30 .

According to ASME B31.3 (see paragraph 302.3.6), the external wind and seismic loads were considered as occasional loads.

\section{Initial calculation data and load cases}

The initial calculation data are presented in table 3 .

Table 3. Initial calculation data.

\begin{tabular}{|c|c|}
\hline Line name & PG-190-110-750-BX1M1-H \\
\hline From & 190 S-1 / N2-750 \\
\hline to & 190 S-2_S-3 / N1-750 \\
\hline Nominal diameter & DN750 \\
\hline Wall thickness [mm] & 9.53 \\
\hline Material & API5L GR.B \\
\hline Flanges & $150 \#$ \\
\hline Design pressure $-\boldsymbol{p}_{\mathbf{1}}[\mathbf{k P a}]$ & 400 \\
\hline Design temperature $-\boldsymbol{t}_{\mathbf{1}}\left[{ }^{\circ} \mathbf{C}\right]$ & 370 \\
\hline Minimum temperature in winter- $\boldsymbol{t}_{\mathbf{2}}\left[{ }^{\circ} \mathbf{C}\right]$ & -29 \\
\hline Corrosion [mm] & 1 \\
\hline Working fluid & Process gas \\
\hline Fluid density [kg/cm $\left.{ }^{3}\right]$ & 0.0000009 \\
\hline Test pressure [kPa] & 730 \\
\hline Test fluid & air \\
\hline Insulation thickness [mm] & 130 \\
\hline Insulation density [kg/cm $\left.{ }^{3}\right]$ & 0.00010 \\
\hline
\end{tabular}


The isometric and the numerical model related to the analyzed system can be seen in figure 1 , respectively figure 2 .

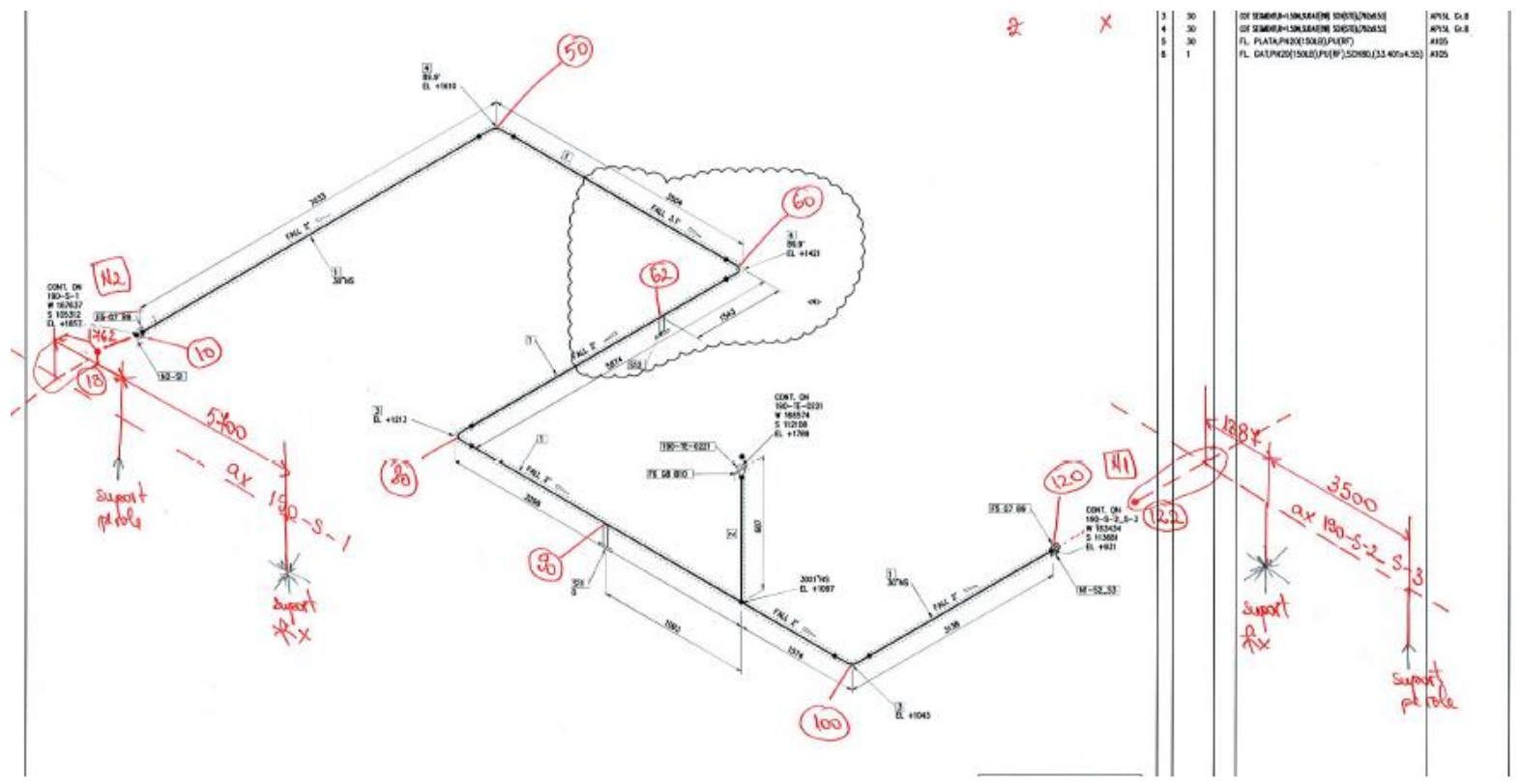

Figure 1. Isometric model related to the analyzed system.

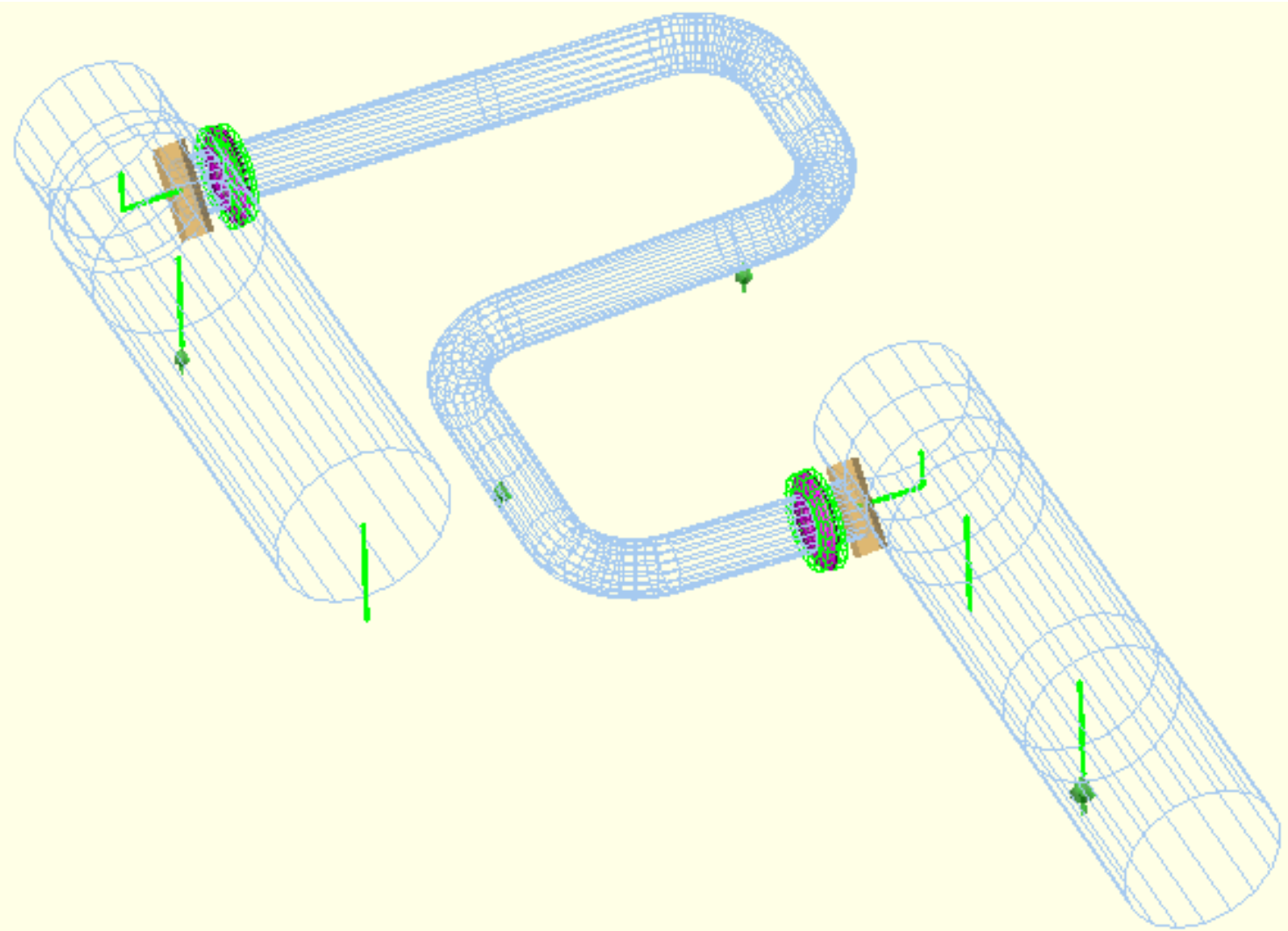

Figure 2. Numerical model related to the analyzed system. 
Tables 4, 5 and 6 summarize the load cases considered in the analysis.

Table 4. Load cases details.

\begin{tabular}{|c|c|c|c|}
\hline & $\begin{array}{r}\text { The case of } \\
\text { - internal pres }\end{array}$ & $\begin{array}{l}\text { quasi-permanent static and occasional load } \\
\text { sure, gravitational loads, thermal expansion } \\
\text { wind and seismic loads }\end{array}$ & \\
\hline & Load case & Individual loads considered & Internretation \\
\hline Symbol & Name & Individual loads considered & interpretation \\
\hline L1 & Gravitational load & $\begin{array}{l}\text { Gravitational loads }(W)-\text { the weight of the } \\
\text { pipe components, the weight of the thermal } \\
\text { insulation and the weight of the working fluid }\end{array}$ & $\mathrm{L} 1=\mathrm{W}(\mathrm{HGR})$ \\
\hline & & $\begin{array}{l}\text { Gravitational loads }(W)-\text { the weight of the } \\
\text { pipe components, the weight of the thermal } \\
\text { insulation and the weight of the working fluid }\end{array}$ & \\
\hline L2 & $\begin{array}{l}\text { Operation under the } \\
\text { specified calculation }\end{array}$ & $\begin{array}{l}\text { Internal pressure corresponding to the } \\
\text { calculation manometric pressure }\left(P_{1}\right)\end{array}$ & $\begin{array}{c}\mathrm{L} 2=\underset{(\mathrm{HGR})}{\mathrm{W}+\mathrm{T} 1+\mathrm{P} 1} \\
\end{array}$ \\
\hline & & $\begin{array}{l}\text { Thermal expansion from the installation } \\
\text { temperature } t_{\text {inst }}=+21{ }^{\circ} \mathrm{C} \text { to the calculation } \\
\text { temperature } T_{1}\end{array}$ & \\
\hline & & $\begin{array}{l}\text { Gravitational loads }(W W) \text { - the weight of the } \\
\text { pipe components and the water weight }\end{array}$ & $\mathrm{L} 3=\mathrm{WW}+\mathrm{HP}$ \\
\hline L3 & Hydraulic Pressure Test & $\begin{array}{l}\text { The internal pressure corresponding to the } \\
\text { test manometric pressure }(H P)\end{array}$ & \\
\hline L4 & Initial system state & $\begin{array}{l}\text { Gravitational loads of pipes without working } \\
\text { fluid }(W N C) \text { - weight of pipe components, } \\
\text { together with the weight of the thermal } \\
\text { insulation and/or the inner covering }\end{array}$ & $\mathrm{L} 4=\mathrm{WNC}(\mathrm{OPE})$ \\
\hline L5 & Primary Static Load (so- & $\begin{array}{l}\text { Gravitational loads }(W)-\text { the weight of the } \\
\text { pipe components, the weight of the thermal } \\
\text { insulation and the weight of the working } \\
\text { fluid }\end{array}$ & $\begin{array}{l}\mathrm{L} 5=\mathrm{W}+\mathrm{P} 1 \\
\quad(\mathrm{SUS})\end{array}$ \\
\hline & & $\begin{array}{l}\text { Internal pressure corresponding to the } \\
\text { calculation manometric pressure }\left(P_{1}\right)\end{array}$ & \\
\hline & & $\begin{array}{l}\text { Gravitational loads }(W) \text { - The weight of the } \\
\text { pipe components, the weight of the thermal } \\
\text { insulation and the weight of the working fluid }\end{array}$ & \\
\hline L6 & $\begin{array}{l}\text { Operation under the } \\
\text { specified calculation }\end{array}$ & $\begin{array}{l}\text { Internal pressure corresponding to the } \\
\text { calculation manometric pressure }\left(P_{1}\right)\end{array}$ & $\begin{array}{c}\mathrm{L} 6=\underset{(\mathrm{OPE})}{\mathrm{W}+\mathrm{T} 1+\mathrm{P} 1} \\
\end{array}$ \\
\hline & & $\begin{array}{l}\text { Thermal expansion from the installation } \\
\text { temperature } t_{\text {inst }}=+21{ }^{\circ} \mathrm{C} \text { to the calculation } \\
\text { temperature } \mathrm{T}_{1}\end{array}$ & \\
\hline
\end{tabular}




\begin{tabular}{|c|c|c|c|}
\hline \multicolumn{4}{|c|}{$\begin{array}{l}\text { The case of quasi-permanent static and occasional loads } \\
\text { - internal pressure, gravitational loads, thermal expansion, } \\
\text { wind and seismic loads }\end{array}$} \\
\hline \multicolumn{2}{|r|}{ Load case } & \multirow{2}{*}{ Individual loads considered } & \multirow{2}{*}{ Interpretation } \\
\hline Symbol & Name & & \\
\hline L7 & $\begin{array}{c}\text { Thermal contraction in the } \\
\text { Stand-By situation during } \\
\text { the winter ("Winter Stand- } \\
\text { By") }\end{array}$ & $\begin{array}{l}\text { Gravitational loads }(W N C)-\text { The weight of } \\
\text { the pipe components and the weight of the } \\
\text { thermal insulation } \\
\text { Thermal contraction from from the } \\
\text { installation temperature } t_{\text {ins }}=+21{ }^{0} \mathrm{C} \text { to } \\
\text { minimum metallic wall temperature } \mathrm{T}_{2}=-29^{\circ} \\
\mathrm{C}\end{array}$ & $\begin{array}{c}\mathrm{L} 7=\underset{(\mathrm{OPE})}{\mathrm{WNC}+\mathrm{T} 2} \\
\end{array}$ \\
\hline L8 & $\begin{array}{c}\text { Operation in winter } \\
\text { conditions ("Operating") }\end{array}$ & $\begin{array}{l}\text { Gravitational loads }(W)-\text { the weight of the } \\
\text { pipe components, the weight of the thermal } \\
\text { insulation and the weight of the working fluid } \\
\text { Internal pressure corresponding to the } \\
\text { calculation manometric pressure }\left(P_{1}\right) \\
\text { Thermal expansion from the installation } \\
\text { temperature } t_{\text {inst }}=+21{ }^{0} \mathrm{C} \text { to the calculation } \\
\text { temperature } T_{2}\end{array}$ & $\begin{aligned} \mathrm{L} 8= & \mathrm{W}+\mathrm{T} 2+\mathrm{P} 1 \\
& (\mathrm{OPE})\end{aligned}$ \\
\hline $\begin{array}{l}\text { L9 } \\
\text { L10 } \\
\text { L11 } \\
\text { L12 }\end{array}$ & $\begin{array}{l}\text { Wind action under the } \\
\text { specified calculation } \\
\text { conditions ("Design") }\end{array}$ & $\begin{array}{l}\text { Gravitational loads }(W)-\text { the weight of the } \\
\text { pipe components, the weight of the thermal } \\
\text { insulation and the weight of the working fluid } \\
\text { Internal pressure corresponding to the } \\
\text { calculation manometric pressure }\left(P_{1}\right) \\
\text { Thermal expansion from the installation } \\
\text { temperature } t_{\text {inst }}=+21{ }^{0} \mathrm{C} \text { to the calculation } \\
\text { temperature } T_{1} \\
\text { The wind distributed load: } \\
\pm \mathrm{WIN} 1=\text { the wind distributed load in } \\
\text { directions } \pm \mathrm{X} \text {; } \\
\quad \pm \mathrm{WIN} 2=\text { the wind distributed load in } \\
\text { directions } \pm \mathrm{Z}\end{array}$ & $\begin{array}{l}\mathrm{L} 10, \mathrm{~L} 9= \\
\mathrm{W}+\mathrm{T} 1+\mathrm{P} 1 \pm \mathrm{WIN} 1 \\
(\mathrm{OPE}) \\
\mathrm{L} 12, \mathrm{~L} 11= \\
\mathrm{W}+\mathrm{T} 1+\mathrm{P} 1 \pm \mathrm{WIN} 2 \\
(\mathrm{OPE})\end{array}$ \\
\hline $\begin{array}{l}\text { L13 } \\
\text { L14 } \\
\text { L15 } \\
\text { L16 }\end{array}$ & $\begin{array}{l}\text { Seismic action under the } \\
\text { specified calculation } \\
\text { conditions ("Design") }\end{array}$ & $\begin{array}{l}\text { Gravitational loads }(W)-\text { The weight of the } \\
\text { pipe components, the weight of the thermal } \\
\text { insulation and the weight of the working fluid } \\
\text { Internal pressure corresponding to the } \\
\text { calculation manometric pressure }\left(P_{1}\right) \\
\text { Thermal expansion from the installation } \\
\text { temperature } t_{\text {inst }}=+21^{\circ} \mathrm{C} \text { to the calculation } \\
\text { temperature } \mathrm{T}_{1} \\
\text { The seismic distributed load: } \\
\pm \mathrm{U} 1=\text { seismic acceleration } a_{s}=0.24 \\
g \text {, in directions } \pm \mathrm{X} \text {; } \\
\pm \mathrm{U} 2=\text { seismic acceleration } a_{s}=0.24 \times g \\
\text {, in directions } \pm \mathrm{Z}\end{array}$ & $\begin{array}{l}\mathrm{L} 14, \mathrm{~L} 13= \\
\mathrm{W}+\mathrm{T} 1+\mathrm{P} 1 \pm \mathrm{U} 1 \\
\mathrm{OPE}) \\
\mathrm{L} 16, \mathrm{~L} 15= \\
\mathrm{W}+\mathrm{T} 1+\mathrm{P} 1 \pm \mathrm{U} 2 \\
\mathrm{OPE})\end{array}$ \\
\hline
\end{tabular}


Table 5. Load cases details.

\begin{tabular}{|c|c|c|c|}
\hline \multicolumn{2}{|r|}{ Load case } & \multirow{2}{*}{ Individual loads considered } & \multirow{2}{*}{ Interpretation } \\
\hline Symbol & Name & & \\
\hline L17 & $\begin{array}{l}\text { Thermal expansion under } \\
\text { the specified calculation } \\
\text { conditions ("Design") }\end{array}$ & $\begin{array}{l}\text { Thermal expansion from the } \\
\text { installation temperature } t_{\text {ins }}=+21{ }^{0} \mathrm{C} \\
\text { to the calculation temperature } T_{1}\end{array}$ & L17 = L6 - L5 (EXP) \\
\hline L18 & $\begin{array}{l}\text { Thermal contraction in the } \\
\text { stand-by situation during the } \\
\text { winter ("Winter Stand-By") }\end{array}$ & $\begin{array}{l}\text { Thermal contraction from the } \\
\text { installation temperature } t_{\text {ins }}=+21{ }^{0} \mathrm{C} \\
\text { to minimum metallic wall } \\
\text { temperature } \mathrm{T}_{2}=-29^{0} \mathrm{C}\end{array}$ & $\mathrm{L} 18=\mathrm{L} 7-\mathrm{L} 5(\mathrm{EXP})$ \\
\hline L19 & $\begin{array}{l}\text { Total thermal expansion } \\
\text { under the specified } \\
\text { calculation conditions } \\
\text { ("Design") }\end{array}$ & $\begin{array}{l}\text { Thermal expansion from the } \\
\text { minimum metallic wall temperature } t_{2} \\
=-29^{0} \mathrm{C} \text { to the calculation } \\
\text { temperature } t_{1}\end{array}$ & $\mathrm{~L} 19=\mathrm{L} 6-\mathrm{L} 7$ (EXP) \\
\hline $\begin{array}{l}\text { L20 } \\
\text { L21 } \\
\text { L22 } \\
\text { L23 }\end{array}$ & Occasional wind load & $\begin{array}{l}\text { The wind distributed load: } \\
\pm \text { WIN1 = wind distributed load } \\
\text { in the directions } \pm X ; \\
\pm \text { WIN } 2==\text { wind distributed load } \\
\text { in the directions } \pm Z\end{array}$ & $\begin{array}{l}\text { L20 = L9 - L6 (OCC) } \\
\text { L21 = L10 - L6 (OCC) } \\
\text { L22 = L11 - L6 (OCC) } \\
\text { L23 = L12 - L6 (OCC) } \\
\text { Represents the exclusively } \\
\text { wind loads applied to the } \\
\text { pipeline system }\end{array}$ \\
\hline
\end{tabular}

Table 6. Load cases details.

\begin{tabular}{|c|c|c|c|}
\hline \multicolumn{2}{|c|}{\begin{tabular}{|l|} 
Load case \\
\end{tabular}} & \multirow{2}{*}{ Individual loads considered } & \multirow{2}{*}{ Interpretation } \\
\hline Symbol & Name & & \\
\hline $\begin{array}{l}\text { L24 } \\
\text { L25 } \\
\text { L26 } \\
\text { L27 }\end{array}$ & $\begin{array}{l}\text { Occasional } \\
\text { seismic load }\end{array}$ & $\begin{array}{l}\text { The seismic distributed load: } \\
\quad \pm \mathrm{U} 1=\text { seismic acceleration } a_{s}=0.24 \times g \\
\text { in directions } \pm \mathrm{X} \text {; } \\
\quad \pm \mathrm{U} 2=\text { seismic acceleration } a_{s}=0.24 \times g \\
\text { in directions } \pm \mathrm{Z}\end{array}$ & $\begin{array}{c}\mathrm{L} 24=\mathrm{L} 13-\mathrm{L} 6 \text { (OCC) } \\
\mathrm{L} 25=\mathrm{L} 14-\mathrm{L} 6 \text { (OCC) } \\
\mathrm{L} 26=\mathrm{L} 15-\mathrm{L} 6 \text { (OCC) } \\
\mathrm{L} 27=\mathrm{L} 16-\mathrm{L} 6 \text { (OCC) } \\
\text { Represents the exclusively } \\
\text { seismic loads applied to the } \\
\text { pipeline system }\end{array}$ \\
\hline $\begin{array}{l}\text { L28 } \\
\text { L29 } \\
\text { L30 } \\
\text { L31 }\end{array}$ & \begin{tabular}{|c} 
\\
Occasional wind \\
resulting load
\end{tabular} & $\begin{array}{l}\text { Gravitational loads }(W)-\text { The weight of the } \\
\text { pipe components, the weight of the thermal } \\
\text { insulation and the weight of the working fluid } \\
\text { Internal pressure corresponding to the } \\
\text { calculation manometric pressure }\left(P_{1}\right) \\
\text { The wind distributed load: } \\
\pm \mathrm{WIN} 1=\text { the wind distributed load in } \\
\text { directions } \pm \mathrm{X} \text {; } \\
\pm \mathrm{WIN} 2=\text { the wind distributed load in } \\
\text { directions } \pm \mathrm{Z}\end{array}$ & $\begin{array}{l}\mathrm{L} 28=\mathrm{L} 5+\mathrm{L} 20(\mathrm{OCC}) \\
\mathrm{L} 29=\mathrm{L} 5+\mathrm{L} 21 \quad(\mathrm{OCC}) \\
\mathrm{L} 30=\mathrm{L} 5+\mathrm{L} 22(\mathrm{OCC}) \\
\mathrm{L} 31=\mathrm{L} 5+\mathrm{L} 23(\mathrm{OCC})\end{array}$ \\
\hline
\end{tabular}




\begin{tabular}{|c|c|c|c|}
\hline \multicolumn{2}{|r|}{ Load case } & \multirow{2}{*}{ Individual loads considered } & \multirow{2}{*}{ Interpretation } \\
\hline Symbol & Name & & \\
\hline $\begin{array}{l}\text { L32 } \\
\text { L33 } \\
\text { L34 } \\
\text { L35 }\end{array}$ & $\begin{array}{l}\text { Occasional } \\
\text { seismic resulting } \\
\text { load }\end{array}$ & $\begin{array}{l}\text { Gravitational loads }(W)-\text { The weight of the } \\
\text { pipe components, the weight of the thermal } \\
\text { insulation and the weight of the working fluid } \\
\text { Internal pressure corresponding to the } \\
\text { calculation manometric pressure }\left(P_{1}\right) \\
\text { The seismic distributed load: } \\
\pm \mathrm{U} 1=\text { seismic acceleration } a_{s}=0.24 \times g \text {, } \\
\text { in directions } \pm \mathrm{X} \text {; } \\
\pm \mathrm{U} 2=\text { seismic acceleration } a_{s}=0.24 \times g \text {, } \\
\text { in directions } \pm \mathrm{Z}\end{array}$ & $\begin{array}{l}\mathrm{L} 32=\mathrm{L} 5+\mathrm{L} 24(\mathrm{OCC}) \\
\mathrm{L} 33=\mathrm{L} 5+\mathrm{L} 25(\text { OCC }) \\
\mathrm{L} 34=\mathrm{L} 5+\mathrm{L} 26(\text { OCC }) \\
\mathrm{L} 35=\mathrm{L} 5+\mathrm{L} 27(\text { OCC })\end{array}$ \\
\hline
\end{tabular}

\section{Results}

In table 7 are given the numerical results regarding the values of maximum displacements in pipes.

Table 7. The values of maximum displacements in pipes.

\begin{tabular}{|l|c|c|}
\hline X-X direction & $\begin{array}{c}-34.8612 \\
\mathrm{~mm}\end{array}$ & Node 126 - Case L19 \\
\hline Y-Y direction & $-1.5682 \mathrm{~mm}$ & Node 49 (from permanent loads) - Case no. L5 \\
\hline Y-Y direction & $-1.5522 \mathrm{~mm}$ & Node 49 (from test loads) - Case no. L1 \\
\hline Y-Y direction & $3.4821 \mathrm{~mm}$ & Node 150 - Case no. 6 \\
\hline Z-Z direction & $\begin{array}{c}-37.4107 \\
\mathrm{~mm}\end{array}$ & Node 49 - Case no. 6 \\
\hline
\end{tabular}

The maximum stresses in pipes can be observed in figure 3 .

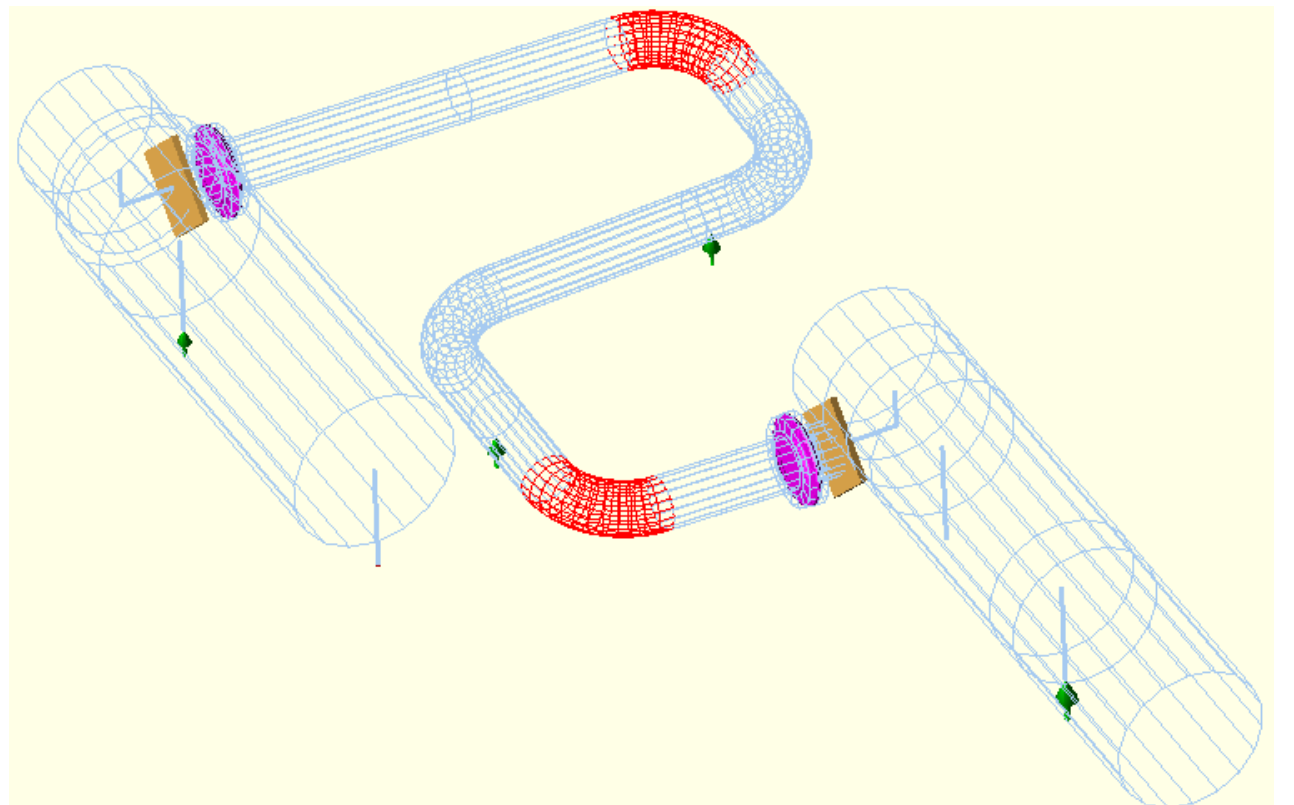

Figure 3. The maximum stress value in case of impeded thermal expansions. 
In table 8 are presented the calculated and the allowable stresses for the analyzed pipe.

Table 8. Comparison between the calculated and allowable stress values for the analyzed pipe.

\begin{tabular}{|c|c|c|c|}
\hline Case & $\begin{array}{c}\text { Calculated stress } \\
\mathbf{k P a}\end{array}$ & $\begin{array}{c}\text { Allowable stress } \\
\mathbf{k P a}\end{array}$ & Percent \\
\hline $\begin{array}{c}\text { Test conditions } \\
\text { (hydraulic or pneumatic) }\end{array}$ & 24705.7 & 217179.0 & 11.4 \\
\hline $\begin{array}{c}\text { Permanent loads } \\
\text { Case 5 }\end{array}$ & 54644 & 116484.3 & 46.9 \\
\hline $\begin{array}{c}\text { Thermal expansion } \\
\text { (maximum from expansion L17...L19) } \\
\text { Case no. L19 }\end{array}$ & 80262.2 & 200839.2 & 40.0 \\
\hline $\begin{array}{c}\text { Ocassional wind loads } \\
\text { (maximum from L28...L31) } \\
\text { Case no. L29 }\end{array}$ & 54761.0 & 154923.4 & 35.3 \\
\hline $\begin{array}{c}\text { Ocassional seismic loads } \\
\text { (maximum from L32...L35) } \\
\text { Case no. L34 }\end{array}$ & 55341.2 & 154923.4 & 35.7 \\
\hline
\end{tabular}

Loads in equipment connections

In tables 9 and 10 are presented the loads for the pipe sockets.

Table 9. Loads for 190-S-1; Socket N2

\begin{tabular}{|c|c|c|c|c|c|c|c|}
\hline \multirow{2}{*}{ Load case } & \multirow{2}{*}{$\begin{array}{c}\text { Node } \\
\text { number }\end{array}$} & \multicolumn{3}{|c|}{ Forces - N } & \multicolumn{3}{|c|}{ Moments - N·m } \\
\hline & & $\mathbf{x}$ & $\mathbf{y}$ & $\mathbf{z}$ & $\mathbf{x}$ & $\mathbf{y}$ & $\mathbf{z}$ \\
\hline $\begin{array}{l}\text { 1(HYD) WNC+P1 } \\
\text { Note } 1\end{array}$ & 13 & -442 & -14935 & -16 & -35587 & 2924 & 9311 \\
\hline $4(O P E) \mathrm{WNC}$ & 13 & -241 & -14993 & -253 & -36059 & 2184 & 9278 \\
\hline $5(S U S) \quad \mathrm{W}+\mathrm{P} 1$ & 13 & 1322 & -15284 & -209 & -37214 & -8673 & 9936 \\
\hline $6(O P E) \mathrm{W}+\mathrm{T} 1+\mathrm{P} 1$ & 13 & 3350 & -13120 & 17495 & -29892 & -80572 & 16383 \\
\hline $7(O P E) \mathrm{WNC}+\mathrm{T} 2$ & 13 & -2883 & -13898 & -3492 & -29046 & 29113 & 9182 \\
\hline $8(O P E) \mathrm{W}+\mathrm{T} 2+\mathrm{P} 1$ & 13 & -2103 & -14171 & -3385 & -30088 & 23910 & 9636 \\
\hline $9(O P E) \mathrm{W}+\mathrm{T} 1+\mathrm{P} 1+\mathrm{WIN} 1$ & 13 & 7618 & -13126 & 16917 & -29775 & -97966 & 16840 \\
\hline $\begin{array}{c}\text { 10(OPE) W+T1+P1- } \\
\text { WIN1 }\end{array}$ & 13 & -925 & -13115 & 18074 & -30010 & -63138 & 15925 \\
\hline
\end{tabular}




\begin{tabular}{|c|c|c|c|c|c|c|c|}
\hline \multirow{2}{*}{ Load case } & \multirow{2}{*}{$\begin{array}{c}\text { Node } \\
\text { number }\end{array}$} & \multicolumn{3}{|c|}{ Forces - N } & \multicolumn{3}{|c|}{ Moments - N·m } \\
\hline & & $\mathbf{x}$ & $\mathbf{y}$ & $\mathbf{z}$ & $\mathbf{x}$ & $\mathbf{y}$ & $\mathbf{z}$ \\
\hline $\begin{array}{c}11(O P E) \\
\mathrm{W}+\mathrm{T} 1+\mathrm{P} 1+\mathrm{WIN} 2\end{array}$ & 13 & 3799 & -13311 & 19394 & -31451 & -85490 & 16345 \\
\hline $\begin{array}{c}\text { 12(OPE) W+T1+P1- } \\
\text { WIN2 }\end{array}$ & 13 & 2900 & -12930 & 15589 & -28333 & -75646 & 16421 \\
\hline $13(O P E) \quad \mathrm{W}+\mathrm{T} 1+\mathrm{P} 1+\mathrm{U} 1$ & 13 & 8828 & -13134 & 16833 & -29821 & -101695 & 16949 \\
\hline $14(O P E) \quad \mathrm{W}+\mathrm{T} 1+\mathrm{P} 1-\mathrm{U} 1$ & 13 & -2139 & -13107 & 18159 & -29963 & -59379 & 15815 \\
\hline $15(O P E) \quad \mathrm{W}+\mathrm{T} 1+\mathrm{P} 1+\mathrm{U} 2$ & 13 & 5174 & -13914 & 23992 & -36414 & -95101 & 15523 \\
\hline $16(O P E) \quad \mathrm{W}+\mathrm{T} 1+\mathrm{P} 1-\mathrm{U} 2$ & 13 & 1465 & -12328 & 10937 & -23355 & -65496 & 17226 \\
\hline \multicolumn{2}{|l|}{ Allowable } & - & - & 45000 & 67500 & 87750 & - \\
\hline
\end{tabular}

Table 10. Loads for 190-S-2 S-3; Socket N1

\begin{tabular}{|c|c|c|c|c|c|c|c|}
\hline \multirow{2}{*}{ Load case } & \multirow{2}{*}{$\begin{array}{c}\text { Node } \\
\text { number }\end{array}$} & \multicolumn{3}{|c|}{ Forces - N } & \multicolumn{3}{|c|}{ Moments - N·m } \\
\hline & & $\mathbf{x}$ & $\mathbf{y}$ & $\mathbf{z}$ & $\mathbf{x}$ & $\mathbf{y}$ & $\mathbf{z}$ \\
\hline $\begin{array}{c}\text { 1(HYD) } \\
\text { WNC+P1 } \\
\text { Note } 1\end{array}$ & 122 & 1397 & -5960 & -1336 & 3176 & 3814 & -2659 \\
\hline $\begin{array}{l}4(O P E) \\
\text { WNC }\end{array}$ & 122 & -24 & -5880 & 96 & 3105 & -159 & -2651 \\
\hline $\begin{array}{c}5(S U S) \\
\mathrm{W}+\mathrm{P} 1 \\
\end{array}$ & 122 & 1890 & -5972 & -1478 & 3092 & 5249 & -2861 \\
\hline $\begin{array}{c}6(O P E) \\
\mathrm{W}+\mathrm{T} 1+\mathrm{P} 1\end{array}$ & 122 & 2254 & -7719 & -12956 & 6373 & -52916 & 1723 \\
\hline $\begin{array}{c}7(O P E) \\
\mathrm{WNC}+\mathrm{T} 2\end{array}$ & 122 & -3733 & -2473 & 2241 & -7199 & -6664 & -8642 \\
\hline $\begin{array}{c}8(O P E) \\
\mathrm{W}+\mathrm{T} 2+\mathrm{P} 1\end{array}$ & 122 & -4048 & -2528 & 1978 & -7234 & -8156 & -8606 \\
\hline $\begin{array}{c}9(O P E) \\
\mathrm{W}+\mathrm{T} 1+\mathrm{P} 1+\mathrm{WIN} 1\end{array}$ & 122 & 6220 & -7798 & -12317 & 6778 & -42090 & 1364 \\
\hline $\begin{array}{c}10(\text { OPE }) \\
\mathrm{W}+\mathrm{T} 1+\mathrm{P} 1-\mathrm{WIN} 1\end{array}$ & 122 & -1716 & -7641 & -13599 & 5967 & -63762 & 2082 \\
\hline $\begin{array}{c}11(O P E) \\
\mathrm{W}+\mathrm{T} 1+\mathrm{P} 1+\mathrm{WIN} 2\end{array}$ & 122 & -1976 & -7776 & -11027 & 6697 & -50712 & 1813 \\
\hline $\begin{array}{c}12(O P E) \\
\mathrm{W}+\mathrm{T} 1+\mathrm{P} 1-\mathrm{WIN} 2\end{array}$ & 122 & -2532 & -7663 & -14890 & 6049 & -55130 & 1632 \\
\hline $\begin{array}{c}13(O P E) \\
\mathrm{W}+\mathrm{T} 1+\mathrm{P} 1+\mathrm{U} 1\end{array}$ & 122 & 8408 & -7843 & -12217 & 6969 & -36482 & 1195 \\
\hline $\begin{array}{c}14(O P E) \\
\mathrm{W}+\mathrm{T} 1+\mathrm{P} 1-\mathrm{U} 1\end{array}$ & 122 & -3909 & -7596 & -13701 & 5776 & -69385 & 2252 \\
\hline
\end{tabular}




\begin{tabular}{|c|c|c|c|c|c|c|c|}
\hline \multirow{2}{*}{ Load case } & \multirow{2}{*}{$\begin{array}{c}\text { Node } \\
\text { number }\end{array}$} & \multicolumn{3}{|c|}{ Forces - N } & \multicolumn{3}{c|}{ Moments - N·m } \\
\cline { 3 - 8 } & & $\mathbf{x}$ & $\mathbf{y}$ & $\mathbf{z}$ & $\mathbf{x}$ & $\mathbf{y}$ & $\mathbf{z}$ \\
\hline $\begin{array}{c}15(\text { OPE }) \\
\text { W+T1+P1+U2 }\end{array}$ & 122 & 1090 & -7972 & -8549 & 7104 & -48973 & 2345 \\
\hline $\begin{array}{c}16(\text { OPE }) \\
\text { W+T1+P1-U2 }\end{array}$ & 122 & 3369 & -7469 & $-\mathbf{1 7 4 3 3}$ & 5634 & -57160 & 1109 \\
\hline \multicolumn{1}{|c|}{ Allowable } & - & - & $\mathbf{4 5 0 0 0}$ & $\mathbf{6 7 5 0 0}$ & $\mathbf{8 7 7 5 0}$ & - \\
\hline
\end{tabular}

\section{Flange analysis - equivalent pressure method}

The flange loads were calculated under operating-design conditions as well as under test conditions.

Under operating-design conditions, the calculations were performed taking into account the loss of thickness by corrosion, for the flanges.

They were checked with the equivalent pressure method and for those that do not fall within the allowed ones, the checks were performed according to ASME Section VIII Div.1. The checks were made considering the same type of flange (material, rating) for the flange with the higher loads according to the equivalent pressure method.

The tables 11 and 12 show the results of the verification calculations with the equivalent pressure method (in the operating-design conditions, respectively test). Flanges that do not fall within the permitted ones are shown with “*”.

Table 11. The verification calculation in the operating-design conditions - Flange Peq : 6 (OPE) $\mathrm{W}+\mathrm{T} 1+\mathrm{P} 1$

\begin{tabular}{|c|c|c|c|c|c|c|c|c|}
\hline NODE & $\begin{array}{c}\text { Axial } \\
\text { Force, } \mathrm{N}\end{array}$ & $\begin{array}{c}\text { Bending } \\
\text { Moment, } \\
\mathrm{N} \cdot \mathrm{m}\end{array}$ & $\begin{array}{c}\mathrm{G} / \mathrm{C} \\
\mathrm{mm} .\end{array}$ & $\begin{array}{c}P \\
\text { Equivalent } \\
\mathrm{kPa}\end{array}$ & $\begin{array}{c}\text { Rating } \\
\text { Temperature } \\
{ }^{\circ} \mathrm{C}\end{array}$ & $\begin{array}{c}\text { Allowable } \\
\text { Pressure } \\
/ \text { Stress }\end{array}$ & $\begin{array}{c}\text { Ratio } \\
\%\end{array}$ & \\
\hline 10 & 17170 & 82187 & 787.40 & 1292.68 & 370.03 & 762.54 & 169.52 & $*$ \\
\hline 20 & & & & & & & & \\
\hline 110 & & & & & & & & \\
\hline 120 & 13114 & 54293 & 787.40 & 993.34 & 370.03 & 762.54 & 130.27 & $*$ \\
\hline
\end{tabular}

Table 12. The verification calculation in the test conditions - Flange Peq : 1 (HYD) WNC+P1

\begin{tabular}{|c|c|c|c|c|c|c|c|c|}
\hline NODE & $\begin{array}{c}\text { Axial } \\
\text { Force, } \mathrm{N}\end{array}$ & $\begin{array}{c}\text { Bending } \\
\text { Moment, } \\
\mathrm{N} \cdot \mathrm{m}\end{array}$ & $\begin{array}{c}\mathrm{G} / \mathrm{C} \\
\mathrm{mm} .\end{array}$ & $\begin{array}{c}\text { Pquivalent } \\
\mathrm{kPa}\end{array}$ & $\begin{array}{c}\text { Rating } \\
\text { Temperature } \\
{ }^{\circ} \mathrm{C}\end{array}$ & $\begin{array}{c}\text { Allowable } \\
\text { Pressure } \\
\text { /Stress }\end{array}$ & Ratio \% & \\
\hline 10 & 395 & 27383 & 787.40 & 1016.47 & 20.00 & 2613.40 & 38.89 & \\
\hline 20 & & & & & & & & \\
\hline 110 & & & & & & & & \\
\hline 120 & 1440 & 3138 & 787.40 & 765.68 & 20.00 & 2613.40 & 29.30 & \\
\hline
\end{tabular}

$P_{1}$ represents the pneumatic test pressure and has the value of $730 \mathrm{kPa}$. 


\section{Conclusions}

The calculation resulted in the stresses values for each finite element of pipe, given by the primary loads (own weight + internal pressure) and the secondary loads (induced by thermal expansion, including the thermal displacements of the equipment connection points). These stresses are below the maximum allowable limits (determined according to ASME code B31.3) which leads to the conclusion that the analyzed piping system satisfies the requirements of the mechanical strength calculation.

The stresses resulting from the pneumatic pressure test are below the maximum allowable limits (determined according to ASME Code B31.3).

The loads (forces and moments) coming from the pipe were compared with the allowable loads for the equipment connections. From this comparison it results that these loads are below the allowable ones. Where the loads resulting from the calculation exceeded the allowable loads on the equipment connections, they were verified using finite element analysis (FEA), there being no overstress in the related connections. The connection meets the ASME requirements in terms of existing stresses.

The flange loads were calculated under the operating-design and test conditions and were verified with the equivalent pressure method (respectively ASME Section VIII Div.1), obtaining admissible values.

In conclusion, it can be said that the piping system is safe and does not endanger the installation safety. This conclusion is valid with the condition that the manufacturer respects all the data provided by the designer (material, wall thickness, geometric dimensions and supports location, etc.).

\section{References}

[1] ASME B31.3. Process Pressure Piping Code, 2006

[2] Caesar II Software

[3] P100-1, Cod de proiectare seismică, 2013

[4] NP-082-04, Cod de proiectare. Bazele proiectării și acțiuni asupra construcțiilor. Acțiunea vântului, 2004 